\title{
Legal Support of Non-Cash Settlements in Economic Activity
}

\author{
Serhii Braichenko ${ }^{1}$, Sergii Dzholos ${ }^{2}$, Artem Kolisnyk ${ }^{3}$, Oksana Koshulko ${ }^{4 *}$, and Larysa Varunts $^{5}$ \\ ${ }^{1}$ Legal Sciences, Cherkasy Educational-Scientific Institute of Banking University, 18028 Cherkasy, Ukraine \\ ${ }^{2}$ Legal Sciences, the Bohdan Khmelnytsky National University of Cherkasy, 18031 Cherkasy, Ukraine \\ ${ }^{3}$ Legal Sciences, Cherkasy Educational-Scientific Institute of Banking University, 18028 Cherkasy, Ukraine \\ ${ }^{4}$ Economic Sciences, Alfred Nobel University, 49000 Dnipro city, Ukraine \\ ${ }^{5}$ Legal Sciences, Kharkiv National University of Internal Affairs, 61080 Kharkiv, Ukraine
}

\begin{abstract}
The article presents the exploring of legal support of non-cash settlements in economic activity. In the article, the complex analysis of the tendencies of the legal regulation of the cashless transfers in commercial activity has been done. Also, the article has been prepared some recommendations on improvement of non-cash settlements, taking into the consideration fact that there are different types of payments under modern economic conditions, which change the approaches to the specific features, protection, and the peculiarities of their usage. Besides, in the article, some problems of the legal regulation of cashless settlements have been investigated according to the papers of international academics from different countries. Also, some legal documents of the state Ukraine in this direction have been analysed in the paper. Among the documents was the Instruction on Cashless Payments in Ukraine in the National Currency; the Civil Code of Ukraine, etc. Therefore, the legal support of non-cash settlements in economic activity is critical and valuable because all the support, as well as all the conditions of the implementation of the modern informational and telecommunication technologies in the activities of the financial institutions, may increasing of the clients' demand on the services of the cashless transfers.
\end{abstract}

\section{Introduction}

The legal support of cashless transfers in economic activity is a very important problem because modern business activity needs a stable and common mechanism of payment.

Therefore, the study and investigation of the new type of transfers and their methods is an actual thing.

The institute of the cashless settlement regulates commercial and civil relations among the client and the bank, as well as administrative and financial and informational relations, connected with the circulation of documents in the paper and digital form due to that fact that during the executing of the noncash transfer appear the documents, prescribed by the legal regulations of the National bank of Ukraine, and usually there is the exchange of the information among banks and payment systems about the transaction of money, which are on the operating account of the payer and the payee.

The legal regulation of the cashless settlements in the commercial activity plays a very important role in the modern world with its modern digital world economy, because the noncash transfers are not only the commercial or legal problem but also the political one, which is connected with the economic safety and demands the strategic approaches to its solution.

So, the correlation of the legal regulation of transfers and the modern legal support of transfers in the commercial activity is a very important problem, and its solution will allow discovering the peculiarities and specific features of the legal regulation of the payments and to define the main directions of the improvement of the commercial and legal regulation of the payments under the modern conditions.

The article aims to make a complex analysis of the tendencies of the legal regulation of the cashless transfers in the commercial activity and the creation of the recommendations on their improvement, taking into the consideration the fact that there are different types of payments under the modern economic conditions, which change the approaches to the specific features, protection and the peculiarities of their usage.

The problems of the cashless settlements and their legal regulation were investigated in the papers by $\mathrm{J}$. Carles Maixé-Altés, E. Mourelle [1], D. Garcia-Swartz, R. Hahn, A. Layne-Farrar [2], M. Krueger, F. Seitz [3], O.V. Dzera [5], I.A. Bezklubyi [6], I.M. Domanetska, M.S. Petrushenko, O.V. Fedusenko, A.O. Fedusenko [8], N.M. Pantielieieva, N.V. Rogova, S.M. Braichenko, S.V. Dzholos, A.S. Kolisnyk [9], N. Pantielieieva, S. Zaporozhets, N. Nagaichuk, O. Bartosh [10], N.M. Panteleeva [11], V.F. Kuzmin [12], Bhaskar Chakravorti, Benjamin D. Mazzotta [15], H.Sheffield [16], J. Henley [17], F. Mokhtar [19], D. Frisby [20], M. Smith [21], C. Quinn [22], A.S. Bohdanovych [23], L.A. Novoselova [24], A.M. Borysova [25], and others.

With all respect to the scientists, who work in this field, it should be noted that the commercial and legal regulation of the payments in the commercial activity needs the next study to make our knowledge deeper and to improve it because the level of the regulation of 
the payments in the commercial activity is not sufficient and some theoretical problems of the legal regulation of the payments among the subjects of the commercial activity are awaiting on the solve.

\section{The results of research}

First, to understand the essence of the cashless settlements it is necessary to formulate their definition. According to the "Instruction on the cashless transfers in Ukraine in the national currency", the cashless settlement is a transfer of funds from the account of the payer to the account of the payee, as well as the transfer of money on the accounts of the recipient of funds, made by the bank on the demand of the natural bodies and legal entities, who pay money in cash to the cash department of the bank [4]. These transfers are made by the bank on the grounds of the payment document in a paper or digital form.

To understand the legal nature of the legal relations in the field of cashless money transfers, it is necessary to characterize such their elements, as their subjects, objects, matter, and legal facts, as the grounds of the appearance, changes, and termination of these legal relations [5].

Firstly, the order of the client of the bank to transfer money from one account to another one is a ground of the appearance of the legal relations on the cashless settlements. At the same time, the order addressed to the bank, is the unilateral transaction [6, p. 250], which should be stated in the written or digital form.

Therefore, the cashless transfers need the existence of the payer's account, created according to his contract with the bank. At the same time, some people may partially disagree with this statement, because the bank account is not always necessary to make the transfer of money. Article number 1089 of the Civil Code of Ukraine, 2003, confirms this and says:

"Under the payment order, the bank shall take responsibility to transfer by a payer's order a certain sum of money at the expense of the funds placed on his account in this bank to the account of a person (recipient) determined by the payer in this or another bank within the term determined by the law, or the banking rules, unless another term is stipulated by the agreement or customs of business practice. Provisions of this Paragraph shall be also applicable to the relations connected with the fund's transfer via the bank by a person having no account in this bank unless otherwise is stipulated by the law, banking regulations or results from the essence of the relations" [7].

Speaking about the German experience, Malte Krueger and Franz Seitz say that in the macroeconomic context the internal costs of businesses, connected with the cash and non-cash payments, are equal for at least 2-2,5\% of GDP [3, p. 34-35].

Secondly, the bank, the payer, and the payee are the subjects of the legal relations on the cashless transfer. It should be noticed that in the different types of payments they might have their special names (nominated bank, payer, recipient of the payment, drawer of check, holder of cheque, the declarant of the letter of credit, beneficiary, etc.).

At the same time, according to the current legislation of Ukraine, payment systems and other financial institutions, which provide service of the money transfer, are also the subjects of the cashless settlements. After the appearance of the cryptocurrency, the peering payment systems, which do not have the central administrator and the issuer of the means of payment, are also the subjects of the cashless settlements.

These payment systems are based on the computer network of the "peer-to-peer" type (or P2P). They are based on the equality of their participants, and their elements may be connected among themselves, in the contrast to the traditional architecture, when only the separate category of participants, the servers, may provide other participants with certain services. There are no "clients" and "servers" in the pure "peer-topeer" network, but there are only the equal nodes, which are at the same time the clients and the servers in the relation to the other nodes of the network. This model of the network interaction differs from the traditional architecture "client-server", where the connection occurs only between the clients and the central server. Such an organization allows keeping working capacity under the conditions of any configuration of its available participants. However, sometimes there are some P2P-networks, which have servers, but their role is not to provide clients with services, but to keep the information about the services, provided by the clients to the network [8, p. 124].

Thirdly, the object of the cashless settlements is the money funds. The function of payment, peculiar to the cash, maybe realized during the payment, made by the non-cash money, which is accounted for on the bank account. The same may be said about the digital money and cryptocurrency.

It is necessary to say few words on such new phenomenon as electronic money and cryptocurrencies.

There are different ideas on the nature of the "electronic money". They may be considered as the units of value, which are kept on the electronic devices. Also, they may be considered as a new type of money. Some authors say that the electronic money is the mean of payment. Other scientists say that the electronic money is the monetary obligation of the person, who issued them, and so on.

The characteristic features of cryptocurrencies are the following:

this money has the digital form;

cryptocurrencies, including the bitcoin, are the units of account, but, at the same time, their legal status is not regulated by the laws, legislation and regulatory acts of many different countries and states of the world;

its legal status is undefined;

its emission is made by the decentralized program;

its issuer is a private company or person;

its mechanism of exchange is a decentralized direct electronic exchange;

they may be used only inside some specific group of people or inside a certain virtual commonwealth, 
and the members of this virtual group or commonwealth should have a special and specific network, and this network is not the usual part of the existing systems of payment of the traditional type;

the issuer of the cryptocurrency defines the offer of the electronic money, and his will plays the main role in this context;

the possibility to redeem is not guaranteed;

the stage of the cryptocurrency formation is characterized by the absence of the supervision and by the lack of the regulation;

the operations with the cryptocurrencies are connected with the high level and a great number of the risks, and these risks may have different types, including the operational risks, credit risks, legal risks and even the liquid risks, etc.;

the cryptography, as well as the mutual and common trust among the participants of this virtual commonwealth, support the necessary level of the stability in the questions of the payment; but, at the same time, the participants of this virtual commonwealth are not responsible for the volatility of the cryptocurrency as a rate of exchange.

The scientists say that there are many positive qualities and characteristics of the cryptocurrencies. The first one is connected with the unique existence of each electronic coin, which may not be used the second time. The second positive quality of the cryptocurrency is the high velocity of the financial settlement. The third one is the high level of security, provided by the transactions, made with the usage of the cryptocurrency. The fourth one is the absence of the supervision in this field. The fifth positive quality of the cryptocurrency is their suitability to be used in the electronic and real payments for the goods, services and works without the assistance of the intermediaries. These five positive qualities of the cryptocurrency together make the sixth one - its efficiency. At the same time, it is necessary to understand, that cryptocurrencies also have the negative characteristics and qualities. One of them is the anonymity, which takes place in the process of the settlement (for example, it will be very hard to police to find and to prove the guilt of the hirer of a contract killer, who pays by cryptocurrency for the murder). The next one is the high volatility of the cryptocurrency price. And, of course, the next one Achilles' heel of the cryptocurrency is its turnover not on the territory of the certain state or worldwide, but only inside the certain virtual commonwealth of the people, who risk to invest their real money into the risk project of the cryptocurrency [9, pp. 413-414].

Also, it is necessary to say that creation of the cryptocurrencies led to the existence of the specific situation, when the cryptocurrencies and the traditional national currencies exist together. This situation changes the essence of the modern economic relations, as well as the movement of funds, in accordance with the tendency of the liberalization in all spheres of the social and economic life. Theoretically, it may reduce the harmful tendencies of the postmodern economy. But, at the same time, the great changes in the circulation of money and in the monetary relations, connected with the spread of the cruptocurrencies, make a serious danger to the traditional financial system of the state [10].

It is necessary to remember that today the cryptocurrencies may be used as the payment instrument, when one of the parties wants to by, and another one wants to sell the real estate or the car, or some other goods. It should be added, that a virtual space permits to make the sale contract, which involve the participants (natural persons and legal entities) from the different countries of the world, and the object of this purchase and sale contract may be different goods, services and works, including the traditional and non-traditional one. We must say that the stock markets, the virtual space, different commonwealths of the cryptocurrencies, the cooperation of the private persons and the financial markets, etc. are developing in our time very fast, and it leads to the growth of the Initial Coin Offering (ICO) market. It helps to find investments for the different business and commercial projects and startups with the help of the digital electronic platforms of the crowdfunding and by other means and methods [11].

The new methods of the investment generation appear and develop in our time because the cryptocurrencies-investors make the fresh ground in this sphere. Also, we must not forget about the existence of the Initial Exchange Offering and about the existence of the Initial Fork Offerings. The first one provides the primary stock offering, and the second one - the primary futures offering. However, it should be noted that the weakest element in the new system of the economic relations is the relations and the cooperation between the private persons and the state on the international, as well as on the national level. But, at the same time the Venezuelan experience shows that the issuance of the national cryptocurrency (Petro) may help to overcome the foreign and international sanctions and the economic crisis. The central banks as well as the governments of many countries, for example such as Norway, Sweden, Canada, the USA, China and others, are thinking about the pluses and minuses of the issuance of the national electronic and digital currencies. The National Bank of Ukraine also tests the project, called the "E-hryvnia" [9, p. 414].

In our time, we may foresee the creation of the free economical system as well as the free markets in future, and this process, probably, will be completed with the help of the new approaches to the economy, based on the possibilities and features of the cyberspace. At the same time, nobody may imagine all aspects and all features of these changes, and that is why today we have different attitudes to and evaluations of the cryptocurrencies and other novelties of modern digital economy. Some people distrust them, and others invest all their store of money into these projects. At the same time, the state needs the stability, and that is why different state authorities make attempts to reduce the risks and threats connected with the undermining of the state privilege to issue money, loss of the benefits of the seigniorage, decrease and depreciation of the traditional national currency, reduction of the money velocity, troubles to the 
efficiency of the state money policy, and its increasing complexity, inability of the state to control the policy and relations in the field of money circulation, possibility to use the cryptocurrency for the illegal purposes (for example arms and drug trade, etc.) [10].

In many different countries, some modern and new technologies may have the lack of the state regulation. For example, the cryptocurrency not always conform to the essence, nature and definition of the "electronic money", given by the legislation, due to the facts that the issuer of the cryptocurrency is not obliged to repay it; the crytpocurrencies may be issued by different bodies, but not by the one center of their issuance; the cryptocurrencies are not connected and bound with the defined non-cash or cash monetary funds. Also, the traditional relations, rights and duties, prescribed by the civil legislation to the cashless resources (for example, the right of claim), may not be applied to the cryptocurrency, because its legal status is not regulated enough by the laws or bylaws. Besides that, the transactions, made by the means of cryptocurrencies, unlike with the cashless transactions, are controlled and supported only by the means of cryptography and the owners' registers, but they are not monitored or controlled by any state organs or commercial banks.

So, in this context, it is very important to answer the question, how and why the participants of the cryptocurrency commonwealth may trust it? The honour is the concept of the feudal epoch, and unfortunately it is forgotten in our time, so the cryptography, the accounting of all transactions as well as the impossibility to change the electronic records without the traces of interference provide the cryptocurrency with the necessary security and produce the trust among the people, who participate in the cryptocurrency commonwealth. The transactions are confirmed by the digital electronic signatures of the former and future owners. The transaction procedure is secured by the blockchain, and the transaction in the cryptocurrency is authorized by the digital electronic signature. The circulation of the cryptocurrency is provided by the addition of the new and the next databases, which are added to the chain during the performance of the transaction, made in a certain cryptocurrency.

At the same time, the payment in cryptocurrency is connected with the specification of the new address of the public character, made by the owner with the usage of his personal or private key. Such transactions are anonymous, because their subjects are not personalized and their personal data is not available to the third person, unlike with the information about the transaction, which is available to persons, who are not the participants of the certain transaction. The virtual money units are kept on the virtual electronic purse on the owner's computer or, sometimes, on the remote server. Cryptocurrencies have the virtual nature and essence, so, they may not be the taken or given into the loan as the money of the traditional type, also the cryptocurrencies may not be the object of the obligation, because they are not the material object and the things, which may be measured by the generic parameters and characteristics in the physical world.
Under these conditions, the Ukrainian Civil Code (as well as the civil codes of many other countries) currently does not regulate the civil rights and duties, connected with the cryptocurrencies or virtual money [9, p. 415].

Fourthly, the rights and duties of the subjects are the matter of the legal relations in the field of cashless transfer $[12$, p. 8]. Their sources are:

- Agreements, because article 1071 of the Civil Code of Ukraine, 2003, "Grounds to Write-off the Funds from the Account" says that "The bank may write off the funds from the client's account based on his instruction. The funds may be written off from the client's account without his instruction based on the court's decision and also in cases determined by the agreement between the bank and the client" [7].

- Laws and bylaws, different legal regulations, banking regulations, and customs of business practice.

The essence of these rights and duties defined in the article no. 1066 of the Civil Code of Ukraine, 2003, which says:

"Under a bank agreement, the bank shall be obliged to accept and enter into an account opened for a client (the account owner) monetary fund's receivable by him, to fulfill the client's instructions on recalculation and issuance of the respective sums from the account, and to complete other account transactions.

The bank shall be entitled to use the funds on the client's account ensuring his right to freely dispose of these funds.

The bank shall have no right to establish and monitor the directions of the client's funds use and establish other restrictions on his right to dispose of the funds at his discretion that is not stipulated by the agreement or by the law.

Provisions of this Chapter shall apply to the other financial institutions while concluding a bank account agreement by them following the issued license as well as to the correspondent accounts, and other bank accounts unless otherwise is established by the law" [7].

Also, it should be added that the bank shall have no right to establish and monitor the directions of the client's funds use and establish other restrictions on his right to dispose of the funds at his discretion, except the cases, when some restrictions on the property rights on the monetary means on the bank account are stipulated, for example, in the cases, prescribed by the Law "On the Prevention and Counteraction to the Legalization (or Laundering) of Proceeds from Crimes, Sponsorship of Terrorism and of the Spread of Weapons of Mass Destruction" [13].

In addition, one of the reasons to reject to perform the transaction may be the suspicion, that the operation is connected with one of the crimes, defined in the Ukrainian Criminal Code of 2001. In this context it is necessary to say, what acts in our time may be considered as a crime, according to the current criminal legislation. 
The article No. 209 of the Ukrainian Criminal Code of 2001 punishes the legalization (or laundering) of the money and other property, which were got (or obtained) by the criminal means [14].

The article No. 209-1 of the Ukrainian Criminal Code of 2001 prescribes the punishment for the intentional violation of the requirements of the legislation on prevention and counteraction to legalization (laundering) of proceeds from crime, terrorist financing and financing of proliferation of weapons of mass destruction" [14].

The article No. 222 of the Criminal Code of Ukraine, 2001, punishes such act, as the fraud with financial resources [14].

In the context of the modern realities and conditions in the world, very popular is the article No. 258-5 of the Criminal Code of Ukraine, 2001, which punishes the financing of the terrorism [14]. At the same time, any lawyer knows that according to the article No. 27 of the Ukrainian Criminal Code, the accessory is one of the forms of the complicity in crime. So, probably, the addition to the Criminal Code of the new article, the article No. 258-5, which punishes the financing of terrorism, contradicts with the logical principle, known from the XIV century as the "Occam's razor", which says that any entity or concept must not be multiplied without the great and reasonable necessity.

Also, it is necessary to remember that many other crimes may be made with the usage of the cryptocurrencies.

Fifthly, the object of the cashless transfers is some act, committed by the subjects of these legal relations, and its result is a payment, made by the transfer of funds from the account of the payer to the account of the payee on the grounds of fee and equivalent commodity relations.

Therefore, the specific informational relations, connected with the circulation of the financial and bookkeeping documents, which contain the information about the payer and the beneficiary of money, appear during the debiting of monetary resources from an account and the crediting funds to an account. At the same time, money, as an object of these relations, does not move from the payer to the payee.

It is necessary to add that modern society is in the economic state where financial transactions are not carried out with tangible money in the form of banknotes or coins. More and more payments are made by transferring digital information between two or more participants of the transaction [15]. At the same time, there is a discussion about the term "cashless society", which is moving towards economic legal relations when money will exist only in digital equivalent. This means that the legal tender is registered and exchanged only in electronic digital form. This method makes it possible to reduce the cost of using the national currency, and also makes it possible for the state to make the control over transactions.

This idea is being discussed primarily because there is a tendency in the world towards a wider use of digital methods of registering and exchanging money in the sale of goods and investments, as well as transactions that have historically taken place. Financial transactions with cash are now often carried out in electronic form [16]. Some governments continue to impose limits on the amount of transactions if there is reason to doubt their legality [17].

As the observations of US scientists show, cashless systems can create problems for people who trust more to the money in cash. These categories include certain groups of the population, such as the poor, the elderly, illegal immigrants, youth, criminals. Electronic transactions require a bank account and skills in using of the payment system. Many people in poor areas do not have or have the limited access to the banking services. In the United States, nearly a third of the population does not have a full range of basic financial services. The research, made by the Federal Deposit Insurance Corporation, shows that approximately 25 percent of households with an annual income of less than $\$ 15,000$ do not have an open bank account. In the United States, more than $7 \%$ of the population does not have a bank account, and in the same time this level exceeds $20 \%$ in some towns and in some locations in the countryside and even $40 \%$ in some areas [18].

During the implementation of the Smart Nation initiative, it was noted that Singapore is steadily moving towards a cashless economy. In this country, more than $14 \%$ of the population is over 65 and they still use cash as the only one method to pay. This is due to the lack of skills in the field of the digital payment methods, unwillingness to solve and eliminate problems associated with the recovery of the lost cards and passwords. They are also a more vulnerable category of the population, which is attacked by fraudsters [19].

It is necessary to say that under the conditions of the digital economy, the payments will be tracked by government agencies. Through tracked transactions, organizations will have access to personal information. Digital transactions are vulnerable because they leave the digital traces. These transactions allow businesses to build customer databases based on their spending and preferences. The problem of database mining depends on the style of the country movement towards a cashless society. Nowadays, we can see how trading companies accumulate personal data and consumer preferences of the population [20]. The possibility to collect this data may have positive and negative consequences. Firstly, the presence of a customer profile can positively affect on the quality of a personal approach to each client, on the guess and predict of his or her desires. The negative consequences of the collecting of the consumers' personal data include the risks that this information may be used for the illegal purposes.

This increases the risks of unauthorized hacking in the cases, if the payment transactions are stored on the servers. Financial cyber attacks and digital crimes also create great risks in the cases of the refusal of the payments in cash. Many companies have losses from information leakage, including the leakage from the payment systems. Electronic accounts are still quite 
vulnerable to unauthorized access and transfer of funds to another account or unauthorized purchases [21].

Also, it should be noted that attacks on telecommunications infrastructure or accidental shutdowns significantly impede the operation of the electronic payment systems. It shows the significant difference of the electronic payment systems from the cash transactions, which may be made with a minimal infrastructure [22].

D.D. Garcia-Swartz， R.W. Hahn， A. Layne-Farrar say that the appearance of the cashless society was foreceed by the scientists in the 1950s, after the appearance of the first general-purpose banking cards, and, of course, now, in the begginning of the XXI century we are much more closer to the cashless society, than it was before [2].

Carles J. Maixe-Altes and Estefanía Mourelle wrote a significant scientific work. The authors propose the indicator, which helps to understand that a certain society is cashless. On their opinion, the indicator which shows that a certain society is cashless is based on the reflection of the proportion (or the percent) of transactions made with the usage of the cashless instruments from the total amount and value of the completed transactions in a certain society $[1, \mathrm{p} .13]$. The authors emphasize on that fact that the situation in the Spanish society has been changed very much during the last 20 years, and that now Spain is much closer to the cashless society, that 2 decades before [1, p. 12].

D.D. Garcia-Swartz， R.W. Hahn, A. Layne-Farrar say in their research on the cashless society that the minor transactions are often made in cash, but the large payments in our time are usually made in the non-cash form; the authors say that cashless payments encrease the welfare of society due to that fact that they are cheaper than the payments in cash (in particular to the customer, but not always to the merchants), but at the same time the authorities of the USA, Australia and the European countries recognize the danger of the great policy interventions, made by the different international digital payment systems in the markets $[2$, p. 195-196].

So, it should be added that it is necessary to understand the legal nature of cashless transfers in commercial activity to define the peculiarities of its legal regulation.

\section{Legal relations in the field of cashless settlements}

The majority of the legal relations in the field of cashless settlements may not exist separately, in a pure manner, because they exist in the connection with the performance of the civil or commercial obligations. The contractual ground of the relations among the banks and other financial institutions and their clients shows the existence of the civil-legal element in the cashless transfers. At the same time, the complicacy of the legal mechanism of the cashless transfer does not allow us to say that they are only the system of the civil-legal constructions. It is necessary to say that the free expression of the will, which is peculiar to the branches of the private law, has limited character in the field of the institute of the payments in the cashless form. The imperative method of the legal regulation dominates there, and it is peculiar to the financial law. It is expressed in such aspects, as:

- The procedure of the cashless settlement is strictly regulated by the imperative rules of the financial law, defined in the special legislation.

- Cashless transfers are the elements of the banking operations and the expression of the functioning of the banking system.

Therefore, they are one of the elements of the object of the legal regulation of the financial law. At the same time, the National Bank of Ukraine plays a great role in the field of the regulation of cashless transfers.

The institute of the cashless transfers regulates not only the material (civil-legal) relations but also the organizational and administrational relations $[23$, p. 392], as well as the commercial and informational relations.

The legal regulation and provision of the cashless transfers in commercial activity based on such obligatory criteria:

1. Cashless transfers are made by the parties of the civil-legal obligation through the operating, current, or other bank accounts, which permit to make payments according to the client's order. This statement is a partly right in our time due to the existence of digital money and cryptocurrencies.

2. The participants of the payment may choose and stipulate in the agreement any form of the payment, provided by the law, the banking regulations, and customs of business practice. Banks may not refuse clients to make these operations unless otherwise established by the law or by the bank account agreement when the bank has a right to refuse to carry out a financial operation.

3. In the payments in the field of civil-legal relations, the debiting of monetary resources from the account may be made by the order of the owner of the account, except to the cases, prescribed by the current legislation or by the agreement between the bank and the client. The will of the owner of the bank account may be expressed in the form of the direct order to the bank to transfer funds or by the cash payment order, as well as in the form of the written consent to make a payment on the demand of the third person.

4. The bank shall have no right to determine and to control the directions of the client's funds use and establish other restrictions on his right to dispose of the funds at his discretion that is not stipulated by the agreement or by the law.

5. The bank, which participates in the payment, based on the civil-legal obligation of the counter agents, is not a part of this obligation. The bank is a part of the bank account agreement, and it is responsible before its 
client only for the performance of this agreement.

6. It is not allowed to limit the client's rights to dispose of funds on his account, except the cases of the seizure of accounts or the suspension of operations on accounts in the cases, prescribed by the law, including the cases, when the transaction is the object of the financial monitoring.

7. The payments from accounts may be made in the presence of the funds on the payer's accounts or at the expense of a bank loan provided to the payer.

8. The non-cash payments should be based on the documents of the prescribed form [24, pp. 47-49].

The operations of any banking institution and the entire banking sphere are full of informational relations, and their main aspect is the information [25, p. 77] because during the performance of the cashless transfers appear the documents, prescribed by the legislation of the central bank, and in the majority of the cases takes place the exchange of the information among the banks and payment systems about the transfer of money, which are kept on the operation accounts.

\section{Conclusions}

It should be noted that under the conditions of the implementation of the modern informational and telecommunication technologies in the activities of the financial institutions, the appearance of the electronic trading, the appearance of the new financial instruments and electronic banking systems, the development of the market of payment services is characterized by the increase of the clients' demand on the services of the cashless transfers.

At the same time, the recommendations on the improvement of the legal regulation of cashless transfers in the commercial activity should be based on the complex analysis of the interests of the participants of the market and the state.

Also, it is necessary to add, that cashless settlements are based on the exchange of the documents, established by the state and prescribed by the legislation, which contains the information about the movement of funds.

The non-cash payments are characterized by the contractual form, which is based on the rules of commercial and civil law.

At the same time, the rules of the financial and the administrative law prescribe the demands to the information, which serves to the circulation of the noncash funds.

Also, it is necessary to add, that the non-cash settlements are the new institute in the economic activity, so it is necessary to understand its economic and legal essence, to avoid the potential risks, which may make damages to the interests of the state, of the society, and of the person.
The existence of the different methods of the noncash settlements and digital payment systems, as well as the existence of the different types of the cryptocurrencies, which are not controlled by the state in the appropriate forms and degrees of inspection, make some risks. So, these modern technologies may be used as the instruments to achieve the illegal purposes, such as the development of the shadow economy, terrorism, human trafficking, drug trade, trade in arms, tax evasion, bribery, corruption, etc.

The existence of the non-cash settlements, of the digital payment systems, and of the different types of the cryptocurrencies undermines the state monopoly of issuing money, and even the status of the national currency as the legal tender.

In the pre-modern society the non-cash settlements, the digital payment systems, and the different types of the cryptocurrencies should be considered as the mixture of theft, fraud and coinage offence. Of course, such evaluation of these modern technologies is not always acceptable under the modern conditions, but the state should do all the best at least to prevent their usage in the criminal and other socially harmful purposes.

So, the state should adopt a system of regulations on the non-cash settlements, the digital payment systems, and the different types of the cryptocurrencies, to define the punishments for their violations, and to create the competent state agencies, which will realize the state policy in this field.

In other case, under the conditions of the development of the cashless society the state will not be able to realize its regulatory and protective functions, to protect the human rights, freedoms and interests in the economic field, and it will be transformed into a virtual state, which has no any real influence on the social life, which will lead to the economic crisis, to the poverty, to the collapse of the society, to anarchy in the state and to the fall of the statehood and the violation of the law and order.

That is why, the legal regulation of the non-cash settlements is a very important economic, legal, social and even political problem, which should be solved by the state.

\section{References}

1. Maixe-Altes, J. Carles and Mourelle, Estefanía. Cash and non-cash payments in a long-run perspective, Spain 1989-2014. Department of Applied Economics, University of A Coruna, A Coruna, Spain. Retrieved from https://mpra.ub.unimuenchen.de/72590/ MPRA Paper No. 72590 (2016).

2. Garcia-Swartz, D.D., Hahn, R.W, Layne-Farrar, A. The Move toward a Cashless Society: A Closer Look at Payment Instrument Economics. Review of Network Economics No. 5(2), 175-198. (2006).

3. Malte Krueger and Franz Seitz. The Importance of Cash and Cashless Payments in Germany: Overview and first estimates. The usage, costs, and 
benefits of cash - revisited: International Cash Conference 2014. Frankfurt am Main: Dt. Bundesbank, p. 15-73 (2014).

4. The Order of the National Bank of Ukraine "On the Adoption of the Instruction on Cashless Payments in Ukraine in the National Currency" No. 22, adopted on the $21^{\text {st }}$ of January, 2004. Retrieved from https://zakon.rada.gov.ua/laws/show/z0377-04 [in Ukrainian].

5. Dzera, O.V. (Eds.). Contract law of Ukraine: special part. Kyiv: Yurinkom Inter [in Ukrainian] (2009).

6. Bezklubyi, I.A. Banking transactions: civil law problems. The Taras Shevchenko National University of Kyiv [in Ukrainian] (2005).

7. The Civil Code of Ukraine No 435-IV, adopted on the $6^{\text {th }}$ of January, 2003. Retrieved from https://zakon.rada.gov.ua/laws/show/435-15\#Text [in Ukrainian] (2003).

8. Domanetska, I.M., Petrushenko, M.S., Fedusenko, O.V., \& Fedusenko, A.O. Simulation model of peering network node functioning // Managing the development of complex systems, No. 12, p. 124132. Retrieved from http://nbuv.gov.ua/UJRN/Urss 20121227 [in Ukrainian] (2012).

9. Pantielieieva N.M., Rogova N.V., Braychenko S.M., Dzholos S.V., Kolisnyk A.S. Current aspects of transformation of economic relations: cryptocurrencies and their legal regulation // Financial and credit activity: problems of theory and practice. Vol. 4, No. 31. pp. 410-418 (2019).

10. Pantielieieva, N., Zaporozhets, S., Nagaichuk, N., \& Bartosh, O. Transformation of financial intermediation in the context of spread of digital trends // Bulletin of the National Academy of Sciences of the Republic of Kazakhstan, No. 3, pp. 144-152 (2019).

11. Panteleeva, N.M. Innovative potential and characteristics of the mechanism of attraction of financing in new technological projects through the issue and sale of new cryptocurrencies to market participants // Proceedings of the $3^{\text {rd }}$ International Conference: New forms of money and financial assets: formation, prospects, risks. (pp. 153-158). Kyiv: KNEU [in Ukrainian] (2017).

12. Kuzmin, V.F. (1971). Raschyotnye pravootnosheniya $\mathrm{v}$ novyh usloviyah hozyajstvovaniya [Settlement legal relationships in the new economic conditions]. Extended abstract of candidate's thesis. Moscow [in Russian].

13. Law of Ukraine Law "On the Prevention and Counteraction to the Legalization (or Laundering) of Proceeds from Crimes, Sponsorship of Terrorism and of the Spread of Weapons of Mass Destruction” № 361-IX, adopted on the $6^{\text {th }}$ of December, 2019. Retrieved from https://zakon.rada.gov.ua/laws/show/361-20\#Text [in Ukrainian].
14. The Criminal Code of Ukraine, adopted on the $5^{\text {th }}$ of April 2001 No 2341-III. Retrieved from https://zakon.rada.gov.ua/laws/show/234114\#Text [in Ukrainian].

15. Bhaskar Chakravorti, Benjamin D. Mazzotta. The cost of cash in the United States (2013) / The Fletcher School Tufts University. Retrieved from https://web.archive.org/web/20161201110118/http :/fletcher.tufts.edu/CostofCash/ /media/Fletcher/ Microsites/Cost $\% 20 \mathrm{of} \% 20 \mathrm{Cash} /$ CostofCashStudy Final.pdf

16. Hazel Sheffield (2015). The UK is getting closer to becoming a completely cashless society. The Independent. May 21, 2015.

17. Henley, Jon (June 4, 2016). Sweden leads the race to become cashless society. The Guardian (June 4, 2016). Retrieved from https://www.theguardian.com/business/2016/jun/0 4/sweden-cashless-society-cards-phone-appsleading-europe

18. Corporation for Enterprise Development (2016). The Most Unbanked Places in America. Retrieved from https://web.archive.org/web/20160820103339/http ://cfed.org/assets/pdfs/Most Unbanked Places in America.pdf

19. Mokhtar, Faris (28 August 2017). Govt will seek to ensure no one is left behind in cashless drive. Today (August 27, 2017). Retrieved from https://www.todayonline.com/singapore/govt-willseek-ensure-no-one-left-behind-cashless-drive

20. Frisby, Dominic (21 March 2016). Why we should fear a cashless world. The Guardian. Retrieved 8 April 2018.

21. Smith M. (1 January 2018). Forever 21: Hackers breached payment system for 7 months. CSO. Retrieved from https://www.csoonline.com/article/3245069/foreve r-21-hackers-breached-payment-system-for-7months-no-encryption-on-pos-devices.html

22. Cristina Quinn (2018). As Society Becomes Increasingly Cashless, Is Massachusetts Ready? GBH News. February 13, 2018. Retrieved from https://www.wgbh.org/news/2018/02/13/news/soci ety-becomes-increasingly-cashless-massachusettsready

23. Bohdanovych, A.S. Cashless settlements using electronic means of payment as a complex legal sub-institution. Journal of Kyiv University of Law, 4, 391-394 [in Ukrainian] (2013).

24. Novoselova, L.A. Cash settlements in business. Moscow [in Russian] (1996).

25. Borysova, A.M. Directions and prospects for improving information banking relations]. Young scientist, 1, 75-78 [in Ukrainian] (2014). 